\title{
Semantic Features of Future Indefinite Tense Form and Oguznames
}

\author{
Imamaliyeva Gunay Serdar \\ Sumgayit State University, Republic of Azerbaijan, (Ph.d Student) \\ ph.d-student[at]hotmail.com
}

\begin{abstract}
Traditionally linguists define the tenses of verb by case and action relation to speaking time. This is based on relation of objective and Grammatik tenses. Time is in objective world not depends on our consciousness. Time is one of the main forms of real existence. Time category has a great role in verbs. "Verb" comes to Azerbaijan Grammatik from Arabian language; the meaning of "verb" is translated to our language as (iş-work, horokot-action and movement). Any work or action connect to time, and this process realize in different time (in present, in past and in future).
\end{abstract}

Key words: oguzname, tenses of verb, future tense, the future indefinite tense form, meaning features

\section{Introduction}

The future indefinite tense form has a great role among verb tenses with its semantic features. Azerbaijani linguists classifying the tense forms have been showed different types of the future indefinite tense form:

According to A.A.Akhundov: 4 semantic features, [1,102105], Z.I.Budaqova 6 semantic features, [2,343], B.A.Khalilov 5 semantic features [3,230], G.Sh.Kazimov 3 semantic features $[4,239]$ :

According to G.A.Fakhraddin kizi, who studied tense categories of verb in Turkish language, noted 4 semantic features of future indefinite tense form. [5,194]. B.Charyarov gave information about 11 semantic and stylistic features of future indefnite tense form in the Turkish language. [6,29-31].

A.A.Akhundov wrote: "Two main features of future indefinite tense form shows itself in the meaning"

1. This type shows doing any actions indecesive in the future.

2. This type denotes active actions and cases for all tenses.

They have some semantic features systematically. [1, p.101].

According to A.A.Akhundov's analysis, it's possible to note following semantic features of the future indefinite tense form in our explored written monuments:

1) Conventionality feature. Doing or not doing of any actions in this meaning feature depend on definite condition. F.ex.

Or galsa quyu artar, övrat galsa qu artar. [7, p.27]:

If husband comes, well increased, if wife comes voice (qu) increased.

Gitito buyursa, it do quyruğunu buyurar. [7, p.43]:

If dog asks other dog, other dog will ask the tail.

Ögümə aĢqo, iki əlim boG̣qo:
Yemaz isəm, baG̦ma taĢqo. [7, p.50]:

Put plov in front of me, put my two hands empty.

If I don't eat, put stone to my head:

Açın könlü doyarsa, gözü toymaz. [7, p.57]:

Even if hungry's soul fed up, their eyes will not fed up.

Sufi sarımsaq yemoz, bulsa sapında gomazdı [7, p.117]:

Sufi dose'nt eat garlic, if finds will not leave stalk

Qara eGog yular ursan, qatır olmaz [7, p.138].

Even if you yoke the black donkey, he'll not be mule.

Yumurda olsa öyünün,

Armud sapına dönar boynun [7, p.177]:

If you have egg for dinner,

Your neck will turn to pear stalk

Case and action in above verbs, examples, "artar-increase", "buyurar-ask", "toymaz-fed up", "yemzz-will not eat", "qomazdl-dont put", "olmaz-will not be", "dönor-turn" can realize only in connection with definite condition. These meaning features were used in S.Alizadeh's "Oguzname", and in "Kitabi-Dede-Gorgud". F.ex:

Dibin ala baqar olsam, dibsüz ă̆ac!

Məni sana asarlar, götürməgil ă̆ac!

If bottom is made from copper, rootless tree!

I will be hang on you, don't let tree! [8, p.46]

Ă̆ saqqalla babamı, ă̆ bürçəklü anamı

Sorar olsam, să̆mı, arğı Q़

White beard grandfather, white wrestle grandmother

If I search, are they live? [8, p.120]

Qazan aydır: Ŏgul, bin kafir öldürsən, kimsə səndən qan davilomaz.

Gazan said: if you kill 1000 enemies, noone ask you blood justise. [8, p.181]

Sayılmağla Oğuz arənlari dükənsə, olmaz

By counting Oguz heros, iinexhaustible [8, p.120] 


\section{International Journal of Science and Research (IJSR) \\ ISSN (Online): 2319-7064}

Index Copernicus Value (2013): 6.14 | Impact Factor (2015): 6.391

As we seeing in given verb examples "asarlar - will be hang", "sorar olsam-if I search", "davilamoz -will not ask", "olmaz - iinexhaustible" case and realize or not to realize the action depends on definite condition. For comparing, let's look through examples on conventionality meaning features in F.Rashiaddin's "Oguzname":

Har no buyursan, boyun ayar, tabe olaram - If you ask anything from me I would obey [10, p.26]

$\dot{G}$ ŞavaÇa çatmasa, siz boyun ayib çoxlu insan qır̆̆ınına yol vermazsiniz, ölkə da talan edilməsə, yaxĢı olmazmı? [10, p.26]

If you would'nt wage the war, not to kill many peoples, not to destroy country, would it be not good?

Qoy bir onu tapım, ondan rüsxət alsam, geri dönüm atasını öldüraram. [10, p.52]

Let me find him, if I get permission, I will kill his father when I come back.

Ogar məni dinlaməsalar va tabelikdən çıxsalar, heç olmasa, oğlun sağ qalar. [10, p.56]

If they dont listen to me, they lose their way, at least your son will be live.

Another exsamples from A.Bahadır's "Shecerey-Terakime”;

Ogar sən müsalmanliğl qabul etsən, man da səni özümə (arvad) edaram. [9, p.53]

If you received muslim, I will marry with you.

Ogər o adam burdan $\dot{\boldsymbol{S}}$ fahana tok getsə, onda sizin adınıza pis olar. [9, p.62]

If that man goes to Isfahan alone, then it will not good for you.

Qoy iki adamı (xanlı̆̆a) yüksəltməsinlər, cünki əgər xan bir olsa el firavan olar, agar (onlar) iki olsa el mahv olar. [9, p.72]

Let they dont raise to khanate 2 men, because if khan is one then peace will be everywhere.

Ogar bu gündən bu harəkətlarini dayandırmasan, mən səni hissa-hissa va tika-tika doğrayıb torpă̆a basdıraram. [9, p.85]

If you dont stop your actions from today, I will cut you by piece.

As we see from samples, here also realizing or not realizing of case and action depends on definite condition.

Conditions in all examples are the same. Thus, realizing or not realizing of any case and action depends on definite condition.

2) The Future Indefinite Tense Form - Sometimes, this meaning features denote action in future indefinite realized in indefinite future tense form. This indefiniteness appears by the help of time adverbials denote future indefinite in sentence. F.ex:

Ban nə vaqt ölürsam, qiyamət ol gün qopar. [7, p.688]

When I die, that day will be end of the world

gimdiki zamanda asıl anılmaz, altun-incü anılır. [..., p.113]
At the present moment true is right word, regards as gold.

Sabahdan buçuqa qlymayan birərdən ikila olmaz. [7, p.119]

Person doesn't screw up their heart from tomorrow, not to screw up from 1 to 2.

In the first exsample the future indefnite tense form meaning of "qopar-will be end of the world" verb is drawn attention distinctly by the help of "ol gün-that day" time adverb.

In the secand and third examples the meaning of future indefnite tense form of "anllur-regards" and "olmaz-not to" verbs express by the help of "Grmdiki zaman-at the present moment" and "sabahdan-from tommorow" time adverbs.

Formally, both of time adverbs are definite but in content they are indefinite in both sentences. Although time adverbs are not used above sentences, the future indefnite tense form shows itself in content of sentences. This feature type was used in A.Bahadir's "Shecerei-Terakime" trace. F.ex:

Neçə ki, biz să̆lq, biz bu sözlardən dönmərik. [9, p.72]

We don't change our mind still alive.

In above example - it's not known when we shall die. So, in general content of sentence the future indefinite tense form shows itself.

3). Possibility feature: Future indefinite tense form denotes action and case which depends any indefinite conditions, beside this, it also denotes possible actions in frame of time. This feature is often used by the verb "olar-may" together different words. [1, p.104] F.ex:

ÜĢünüGyılanı qoynuna qoyma, isincaq soni soqar [7, p.58] Dont take the shivering snake on your neck, get warmer, bite you.

Qocalıq...öskürak artırar. [7, p.136]

Senility.... increase the caught.

YaxGııöz ila yılan indan çıqar. [7, p.175]

To take snake out with your sweet tongue.

In above sentences the verbs "soqar-bite", "artırar-increase", "çıqar-take out", denote possible actions in future. As we see, the verb "olar-may" isn't used in above sentences. But this feature isn't belong to auxiliary verb, it's the feature belongs to the indefinite tense form. Possibility features have been used in our written monument "Kitabi-Dede-Gorgud".

Keyikə atarkən oqla səni urar öldürər [8, p. 30]; To shoot an arrow to partridge, it would kill you.

Kafirlar aydır: "gimdi yigidi atar-yıqar, saror-pırtar [8, p.108]. Giaours said: "Just now braves would be killed"

In given examples, the verb "öldürər-would be killed" denotes possible action in future. This type of feature have been used in F.Reshidedin's “Oguzname”. 


\section{International Journal of Science and Research (IJSR) \\ ISSN (Online): 2319-7064}

Index Copernicus Value (2013): 6.14 | Impact Factor (2015): 6.391

Bu yolla biz xalqın inamını qazanarıq və özümüzə tabe edərik $[10, \mathrm{p} .25]$. By this way, we would get confidence of people and subordinate.

The verbs "qazanarı-would get (earn)", "tabe edərik-would subordinate" which used in above, denote realizing possible actions in frame of time in future.

4). Reciprocal feature: Sometimes cases and actions in future indefinite tense form in this type of features are compared. Mainly, in the same sentence suffixes -ar, -or used in affirmative sentence, $-\boldsymbol{m a z}, \boldsymbol{- m} \boldsymbol{z}$ used in negative sentence within together. F.ex:

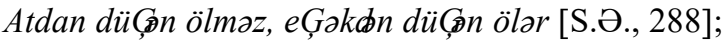

Who gets off horse will not die, who gets off donkey will die.

Halalzadə bazar edər, haramzadə bozar [S.Ө., 88];

Permitted will do market, bastard will break.

Haqlu var, haqsız çıqar; haqsız var, haqlu çıxar [S.Ө., 90]; Right will take out wrongful, wrongful will take out justify.

As seen from the samples, both sides of the complex sentences are compared by the the verbs "ölmaz - ölar"- "will not die-will die", "bazar edor - bozar"-"will do market-will break", "haqsız çıqar - halqu çıxar" - "will take out wrongful-will take out justify".

For comparing, let's look through examples from "KitabiDede-Gorgud":

Yad oğulu saqlamaqla oğul olmaz,

Böyüyəndə salur gedər, gördüm diməz [8, p.19]

Growing up the strange son wouldn't be son

When he grows up, will go away without saying nothing

BaĢndă̆ tuğulğanı nə ögərsən, marə kafir,

Baর̧̣mdağı bözkümcə galməz mana [8, p.39];

Why do you proud of your helmet, bad giaour,

Your cap does not fit on me

Biri aydır: "Mərə, mizim öksüzlı̆̆ımız yetməzmi, bizi niyə urarsan?" [2, p. 146] One said: "Bad giaour, our orphanhood isnt enough, why do you bit us? "

The verbs "gedər-dinməz" - "go away-without saying nothing", "ögərsən-gəlməz" - "proud of - does not fit on", "yetməzmi-urarsan" - "isnt enough-bit" create reciprical feature with affirmative and negative forms of the future indefinite tense form.

5). Dynamic and static features: This type differing from other tenses, denotes dynamic and static cases and actions of the future indefinite tense formc. This feature can used in all examples of future indefinite tense form (verbs). F.ex:

Öksüz oğlan göbagin kandü kəsər [7, p. 35];

Brave can cut his navel himself.
Dövlatlü evin tütüni askik olmaz [7, p. 100];

Rich house hasnt shortage tobacco.

Geybi Allahdan ğeyri kimsa bilmaz [7, p. 129].

God kmows all secrets.

Dynamic and static features in "Kitabi-Dede-Gorgud": f.ex.

Mərə kafir, Qazanın anası qarıuubdur oğul verməz [8, p.48]; Bad giaour, Gazan's mother was old, she would'nt give birth to.

Ata dururkan oğul alinmi öparlar [8, p.54];

When father stands will it right to kiss son's hand?

Ozrayll aydır: "Moro doli qavat, mana no yalvararsan, Allah Taalaya yalvar [8, p.97];

Azrail said: Giaour, why would you beg me, beg pardon from the God.

Mərə kafir, mənim adım bilməzmisən? [8, p.162].

Giaour, would'nt you know my name?

The verbs "oğul vermaz- would'nt give birth to”, “öporlarwill it right to kiss", "yalvararsan- beg me", "bilmazmisanwould'nt you know" used in above exsamples denote dynamic and static cases and actions.

For comparing, let's look through F.Reshideddin's "Oguzname".

Har hansı bir uĢ̆ğın bizə, bizim məbudumuza arxa çevirib ona nifrat etmasi ila biz neca barlGa bilarik. [10, p.12]; - How we reconciled to the child turning back to us.

Məni özünüzla götürsəniz yaxĢ olmazmı? [10, p.15] Would'nt it be good if I come with you?

Examples belong to this meaning features have been used in A.Bahadir khan's "Shecerei-Terakime" trace. F.ex:

[Takcə Tanrl] göy qübbəsinin [vaziyyatinin] iÇ̣ini vo firlanmasını unutmağa qoymaz; onunla [onun köməyi ila] bu asandir [9, p97]. God will not permit to forget sky's work, difficultness is forgetten only by God. Its easy with God.

Here is "qoymaz-will not permit" is dynamic and static action.

5) Denotes all tenses: proverbs, sayings, aphorisms and etc can expressed in all tenses by future indefinite tense and these meaning colors.

Oski düG,man dost olmaz, sski dost düĢman olmaz [7, p. 42];

Old enemy wouldnt be a friend, old friend wouldnt be enemy.

Adomi var, quzl alma naqÇdur,

Having Adem is golden appile pattern. [7, p. 64]

This meaning feature have been used in written monument "Kitabi-Dede-Gorgud". F.ex:

Takəbbürlik eylayəni Tanrl sevməz [8, p.19];

God doesn't like swagger persons.

Yad oğulu saqlamaqla oğul olmaz, böyüyəndo salur gedər, gördüm deməz [8, p. 19]; To bring up strange son wouldnt be son, when he grow up, go away without saying nothing. 
Qolça qopauz götürüb, eldən-ela, bəğdən-bəğə ozan gəzər [8, p. 21]; Golcha who plays saz (national musical instrument of Azerbaijan) and walking step by step.

In above exsamples, suffixes -ar, -ər, -maz, -məz express not only future tense, express all tenses. For comparing, let's look through examples from F.Reshideddin's "Oguzname".

Nəğgi qoyub nisyə dalınca qaçmaq olmaz [10, p.16].

Get something in in cash, not in credit.

\section{References}

[1] Akhundov A. Tenses of verbs. Baki: “AFL” Press, 1961, $135 \mathrm{p}$.

[2] Modern Azerbaijan Language. II part. "Science" 1980, $590 \mathrm{p}$.

[3] Khalilov B. Morphology of Modern Azerbaijan language, II part. Baki:’Nurlan” press, 2007, 351p.

[4] G.Sh.Kazimov Modern Azerbaijan Language. Morphology.Baki: Science and education, 2010, 400p.

[5] Gulnara Faxraddin kizi. Time category of Turkish language. Baki: "Nurlan" press, 2010, 262p.

[6] Чарыярова Б.С. Времена глагола в тюркских языков юго-западной группы. АДД. Ашхабад, 1870, с.85.

[7] Alizadeh Samet. "Oguzname". Baki: "East-West" press, 2006, 213p.

[8] Kitabi-Dede-Gorgud. Baki: “Onder" press, 2004, 375p.

[9] A.Bahadir khan. "Shecerei-Terakime". Baki: Polygraphs Union, 2002, 131p.

[10] Reshiddedin F. "Oguzname". Baki: ASP-Polygraphs union, 1882, 71p.

\section{Author Profile}

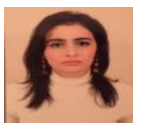

Gunay. S. Imamaliyeva is a Ph.D student of Azerbaijan language and Linguistcs department of Sumgayit State University. She is studing on her doctoral work named "Time category of verbs in Oguzname". Her specialization is Linguistics. She is working as Azerbaijan language teacher in Sumgait State University. 